\title{
Comparison of a direct live count and an improved quantitative protargol stain (QPS) in determining abundance and cell volumes of pelagic freshwater protozoa
}

\author{
Gerald Pfister ${ }^{1,2, *}$, Bettina Sonntag ${ }^{2}$, Thomas Posch ${ }^{2}$ \\ ${ }^{1}$ Institute of Limnology, Austrian Academy of Sciences, Gaisberg 116, A-5310 Mondsee, Austria \\ ${ }^{2}$ Institute of Zoology and Limnology, University of Innsbruck, Technikerstr. 25, A-6020 Innsbruck, Austria
}

\begin{abstract}
To compare the efficiency of 2 common methods in protozooplankton ecology the protozooplankton spring community of a mesotrophic prealpine lake was investigated. A direct live count and a routinely applicable modification of a quantitative protargol stain (QPS) were evaluated with respect to their reliability in determining and quantifying pelagic freshwater ciliates and heterotrophic and mixotrophic flagellates. Cell counts of most ciliate species from field samples as well as of cultures were not significantly different when estimated by the 2 methods. The QPS allowed for detailed ciliate identification even for species not determinable by the applied direct live observation. Consequently, $60 \%$ of all determined species from field samples were identified exclusively by means of the QPS. Both flagellate and ciliate cell volumes showed high and species-specific shrinkage after the QPS, thus underestimating calculations of cell volumes. After the QPS, aloricate ciliates shrank to less than $20 \%$ of their respective live volumes, whereas the armoured Coleps spetai did not shrink significantly. Thus, drawbacks in applying average conversion factors for cell volume calculations after the QPS are discussed. Total heterotrophic and mixotrophic flagellate numbers counted by the QPS method were $37 \%$ of the direct live counts. Based on these results the advantages and disadvantages of the 2 tested methods used in protozooplankton analysis are summarized.
\end{abstract}

KEY WORDS: Ciliates · Fixation · Flagellates - Shrinkage · Quantification

\section{INTRODUCTION}

Protozoa are major plankton components in most aquatic systems, feeding on bacteria, auto- and heterotrophic pico- and nanoplankton (e.g. Porter et al. 1985, Müller 1991, Hall et al. 1993, Šimek et al. 1995). Hence, by their grazing activities, they provide particulate organic matter (POM) to higher trophic levels and dissolved nutrients (DOM) to bacteria (Arndt 1994). Because of their small size, rapid growth and high metabolic rates, they are an important link in microbial food webs even when appearing in low abundance (Fenchel 1987). Their high turnover rates and short generation times allow many species to

\footnotetext{
•E-mail: gerald.pfister@uibk.ac.at
}

respond immediately to changing environmental conditions. Thus, protozoa may be sensitive and highly valuable bioindicator organisms in water quality analyses (e.g. Sládeček 1973, Foissner 1988, Berger et al. 1997). An exact determination of protozoan species is therefore a prerequisite to evaluate their ecological importance. Since a direct live observation of protozoa has to be performed immediately after sampling and requires some experience (see below), quantitative investigations are often carried out on fixed samples. Such established methods are epifluorescence microscopy for enumerating fluorescently labeled flagellates (Haas 1982, Caron 1983, Sherr et al. 1993) and the quantification of ciliates by means of sedimented Lugol-fixed samples (Utermöhl 1958). Unfortunately, these methods provide only poor taxonomic information. On the other hand, modern determination meth- 
ods for ciliates (revised in Foissner 1991) allow for detailed taxonomy, but do not result in reliable quantitative data. The quantitative protargol stain (QPS) developed by Montagnes \& Lynn (1987) is a promising method combining the identification and enumeration of ciliates after silver impregnation. However, QPS is a time consuming compromise solution on both taxonomic and ecological grounds. Recently, Montagnes \& Lynn's method has been modified by Skibbe (1994) resulting in a routinely applicable procedure duration of about $5 \mathrm{~h}$.

It is well known that fixation of protozoa can lead to both shrinkage and swelling as well as to total destruction of cells (Choi \& Stoecker 1989, Sime-Ngando \& Groliere 1991, Jerome et al. 1993, Leakey et al. 1994). Unfortunately, the QPS is poorly investigated with respect to the quantitative nature regarding both cell numbers and volumes (Montagnes \& Lynn 1987, Jerome et al. 1993, Skibbe 1994). In the present study, a slight modification of Skibbe's (1994) QPS and a direct live observation (droplet method after Massana \& Güde 1991) were compared. The 2 methods were tested both qualitatively and quantitatively in order to evaluate their accuracy and reliability in determining freshwater protozooplankton communities. For that reason the investigations were carried out on a natural flagellate and ciliate population of the prealpine mesotrophic Lake Mondsee (Austria), as well as on different ciliate species originating from batch cultures.

\section{MATERIALS AND METHODS}

Ciliate cultures. The ciliate species Halteria grandinella (Oligotrichida), Cyclidium glaucoma and Cinetochilum margaritaceum (Hymenostomatida) were isolated from Mondsee and cultivated in batch cultures at $20^{\circ} \mathrm{C}$. Cryptomonas sp. (strain 26/80, formerly Rhodomonas sp. strain $26 / 80$ from the culture collection of algae in Göttingen, kindly provided by I. Bruchmüller, MPI Plön, Germany) was grown on Woods Hole MBL medium (Guillard \& Lorenzen 1972) and was supplied as food for $H$. grandinella. The 2 hymenostome species were fed on bacteria grown on wheat grain cultures.

Live observation. Samples from Mondsee $\left(47^{\circ} 50^{\prime} \mathrm{N}\right.$, $13^{\circ} 23^{\prime} \mathrm{E}, 480 \mathrm{~m}$ above sea level) were taken on $21 \mathrm{May}$ 1997 at 2,6 and $12 \mathrm{~m}$ depth with a 51 Schindler-Patalas sampler. About $750 \mathrm{ml}$ of unfiltered water was poured into clean $1 \mathrm{l}$ plastic bottles, stored in a cooling box and transported to the laboratory immediately. Both flagellates and ciliates were enumerated using the 'droplet method' after Massana \& Güde (1991) 1 to $2 \mathrm{~h}$ after sampling. All observations were performed on a microscope (Zeiss Axioplan) equipped with phase contrast and interference contrast (DIC) at a low magnification
(125 $\times$ for flagellates, $40 \times$ for ciliates) without a cover slip. Live observations of both ciliates and flagellates were done in 4 replicates. One hundred drops of 1 to $10 \mathrm{\mu l}$ each were pipetted onto a glass slide and quickly counted for flagellates using dark field illumination. Dimensions of the 4 flagellate species Dinobryon bavaricum, $D$. divergens, Dinobryon sp. and Salpingoeca sp. from the field samples were measured by means of image analysis. These 4 species represented a large part of the mixotrophic flagellate community at the time of sampling and were selected due to their good recognizability after the QPS. For enumeration of ciliates 20 drops of $250 \mu \mathrm{l}$ each for the field samples and Halteria cultures (each droplet containing about 5 to 10 ciliates) and 50 drops of $1 \mu \mathrm{l}$ for the Cyclidium and Cinetochilum cultures (each droplet containing about 5 to 10 ciliates) were observed using DIC. Flagellate and ciliate abundances per milliliter were calculated from the respective number of cells per each drop counted and the mean values of the 4 replicates were compared to the respective numbers from the QPS preparations. Identification of live ciliates was possible at least to genus level at a magnification of $400 \times$

Quantitative protargol stain. Protargol preparations of both flagellates and ciliates were achieved according to Skibbe (1994) with some modifications described below. The QPS is based on 6 main steps: (1) fixation of cells with Bouin's fixative, (2) concentration of cells on cellulose nitrate filters, (3) embedding of cells in a thin layer of agar, (4) protargol impregnation, (5) dehydration and (6) mounting in Canada balsam. The method provides permanent slides which allow both qualitative and quantitative evaluation of pelagic protists.

We made the following modifications to Skibbe's method description: In Step 1 we used $5 \mathrm{ml}$ of fixative for $95 \mathrm{ml}$ water sample. In Step 2, 1 to 4 (cultures) and 9 to 30 (field samples) $\mathrm{ml}$ were filtered on cellulose nitrate filters with counting grid (pore size $0.8 \mu \mathrm{m}$, Sartorius). In Step 3 we embedded the filters in $3.6 \%$ liquid and warm $\left(60^{\circ} \mathrm{C}\right)$ agar $(0.36 \mathrm{~g}$ Agar agar, no. 1613 , Merck, dissolved in $10 \mathrm{ml}$ of particle-free distilled water) and left them in 10\% formaldehyde for $15 \mathrm{~min}$ to harden. During the protargol impregnation (Step 4), the usage of $0.5 \%$ yellow gold chloride (Fluka) for 1 to 2 s gave the best results. Finally, in Step 6, the preparation of Canada balsam (No. 1686, Merck) was done by mixing it in Rotihistol (Roth) in order to reach a 'honey-like' viscosity. The temperature for the hardening of preparations embedded in Canada balsam was $60^{\circ} \mathrm{C}$ for at least $12 \mathrm{~h}$

The samples were impregnated with protargol within a few days after fixation. All preparations were investigated by means of DIC at a magnification of 
$500 \times$ in 4 replicates. Ciliate counts are based on the evaluation of 5 counting grids per filter, which was equivalent to $32.7 \%$ of the total area. In addition, the whole filter area was investigated at a magnification of $125 \times$ to avoid a loss of large and rare species. Thus, a minimum of 200 to 300 cells per sample was counted.

Measurements and statistical analysis. Measurements on both living and fixed cells were performed with the help of a semiautomatic image analysis system (LuciaM, Laboratory Imaging, Prague, Czech Republic). Live measurements were performed on captured images to avoid an interference of movements with our measurements. The length and width of 20 to 50 cells of each species were measured. Dimensions of the loricate species Dinobryon spp., Salpingoeca sp. and Codonella cratera did not include the loricae. Cell volumes were calculated by approximations of simple geometric shapes.

Statistical analysis of our data was performed according to Fowler \& Cohen (1990). Calculations were performed with the help of the Statistica 5.0 and SigmaStat 4.0 software packages for Windows. All data were checked for their normal distribution by the Shapiro-Wilks $W$-test. Further treatment included a Student's t-test to detect potential significant differences in our data when normally distributed. An additional Levene test and a power-test were performed for each set of data to check the reliability of the respective statistical test. Non-parametric data were compared by the Mann-Whitney Rank Sum test. Significant differences were assumed at $p<0.05$, highly significant differences were assumed at $\mathrm{p}<0.01$ (see below for detailed discussion).

\section{RESULTS}

\section{Ciliates}

\section{Cell numbers}

The mean ciliate abundance was not significantly different $(p>0.05)$ for some ciliate groups using either the live observation or the QPS method. However, significant differences $(\mathrm{p}<0.05)$ could be detected for naked oligotrichs (all depths), prostomatids $(6 \mathrm{~m})$,
Table 1. Comparison of cell numbers for ciliates and flagellates after live observation and the quantitative protargol stain (QPS). Mean \pm SD. P: power of $t$-test preparations (live counts $=100 \%$ ), $\mathrm{D}$ : difference between treatments, 'significant difference $(p<0.05), \cdots$ highly significant difference $(p<0.01)$, : MannWhitney test due to lacking normality distribution of data

\begin{tabular}{|c|c|c|c|c|c|c|}
\hline & $\begin{array}{l}\text { Depth } \\
\text { (m) }\end{array}$ & $\begin{array}{c}\text { Live } \\
\text { (cells } \mathrm{ml}^{-1} \text { ) }\end{array}$ & $\begin{array}{c}\text { QPS } \\
\text { (cells ml }{ }^{-1} \text { ) }\end{array}$ & $P$ & $\begin{array}{l}\mathrm{L} / \mathrm{Q} \\
(\%)\end{array}$ & $\mathrm{D}$ \\
\hline \multicolumn{7}{|l|}{ Field community } \\
\hline \multirow{3}{*}{ Prostomatida } & 2 & $9.8 \pm 1.9$ & $8.6 \pm 1.2$ & 0.05 & 88 & \\
\hline & 6 & $22.7 \pm 4.3$ & $37.9 \pm 5.0$ & 0.97 & 167 & .. \\
\hline & 12 & $21.8 \pm 1.9$ & $18.3 \pm 1.5$ & 0.65 & 84 & \\
\hline \multirow[t]{3}{*}{ Gymnostomatida } & 2 & $0.6 \pm 0.7$ & $0.6 \pm 0.5$ & 0.05 & 100 & \\
\hline & 6 & $0.6 \pm 0.7$ & $0.9 \pm 0.3$ & 0.05 & 150 & \\
\hline & 12 & $0.2 \pm 0.4$ & $0.6 \pm 0.2$ & 0.32 & 300 & \\
\hline \multirow[t]{3}{*}{ Hymenostomatida } & 2 & $0.6 \pm 0.7$ & $1.8 \pm 0.3$ & 0.67 & 300 & $\cdot$ \\
\hline & 6 & $0.2 \pm 0.4$ & $1.4 \pm 0.3$ & 0.98 & 700 & $\cdots$ \\
\hline & 12 & $0.2 \pm 0.4$ & $0.8 \pm 0.3$ & 0.42 & 400 & \\
\hline \multirow{3}{*}{$\begin{array}{l}\text { Oligotrichida } \\
\text { (naked) }\end{array}$} & 2 & $10.0 \pm 1.6$ & $5.2 \pm 1.0$ & 0.99 & 52 & $\cdots$ \\
\hline & 6 & $13.4 \pm 3.8$ & $3.5 \pm 1.2$ & 0.98 & 26 & $\cdots$ \\
\hline & 12 & $4.2 \pm 1.5$ & $1.6 \pm 0.5$ & 0.74 & 38 & $\cdot$ \\
\hline \multirow{3}{*}{$\begin{array}{l}\text { Oligotrichida } \\
\text { (loricate) }\end{array}$} & 2 & $2.4 \pm 2.1$ & $3.1 \pm 0.5$ & $\sim$ & 129 & \\
\hline & 6 & $0.6 \pm 0.8$ & $0.8 \pm 0.1$ & 0.79 & 133 & \\
\hline & 12 & $1.2 \pm 1.4$ & $1.1 \pm 0.3$ & $\sim$ & 92 & \\
\hline \multirow[t]{3}{*}{ Peritrichida } & 2 & $0.2 \pm 0.4$ & $0.8 \pm 0.1$ & 0.88 & 400 & $\cdot$ \\
\hline & 6 & $0.8 \pm 0.6$ & $0.5 \pm 0.2$ & 0.07 & 63 & $\cdot$ \\
\hline & 12 & $0.2 \pm 0.4$ & $0.2 \pm 0.1$ & 0.99 & 100 & \\
\hline \multicolumn{2}{|c|}{ Total ciliates (average) } & $29.9 \pm 4.4$ & $29.5 \pm 3.1$ & 0.05 & 99 & \\
\hline \multicolumn{2}{|c|}{ Total flagellates (average) } & $1363.3 \pm 326.5$ & $414.2 \pm 71.2$ & 0.99 & 30 & $\cdots$ \\
\hline \multicolumn{7}{|l|}{ Cultures } \\
\hline \multicolumn{2}{|l|}{ Halteria grandinella } & $18.6 \pm 1.4$ & $14.0 \pm 6.2$ & 0.15 & 75 & \\
\hline \multicolumn{2}{|c|}{ Cyclidium glaucoma } & $1965.3 \pm 382.5$ & $1252.3 \pm 160.5$ & 0.79 & 64 & $\cdot$ \\
\hline \multicolumn{2}{|c|}{ Cinetochilum margaritaceum } & $30.6 \pm 21.5$ & $10.4 \pm 3.4$ & $\sim$ & 34 & \\
\hline
\end{tabular}

hymenostomes ( 2 and $6 \mathrm{~m}$ ) and peritrichs ( $2 \mathrm{~m}$ ). Except for naked oligotrichs, these differences were due to higher counts in the QPS samples. Naked oligotrich numbers were significantly (up to $100 \%, \mathrm{p}<0.05$ ) higher in live counts at all depths investigated (Table 1, Fig. 1). Using counts from both methods, total ciliate abundance in Mondsee ranged from about 20 cells ml $\mathrm{m}^{-1}$ at $2 \mathrm{~m}$ depth to about 40 cells $\mathrm{ml}^{-1}$ at $6 \mathrm{~m}$ depth. Mean total ciliate abundance was almost identi$c a l$ and not significantly different $(p>0.05)$ after both live observation and QPS (Table 1, Fig. 2).

The determination of abundance for the 3 ciliate species from cultures (Halteria grandinella, Cyclidium glaucoma and Cinetochilum margaritaceum) showed a similar pattern. Although differences in live and QPS counts were higher than in field samples, only the live counts for C. glaucoma were significantly higher ( $\mathrm{p}<$ $0.05)$ than the QPS counts. No significant differences ( $p>0.05$ ) in the abundance of $H$. grandinella and $C$. margaritaceum could be detected for the applied 

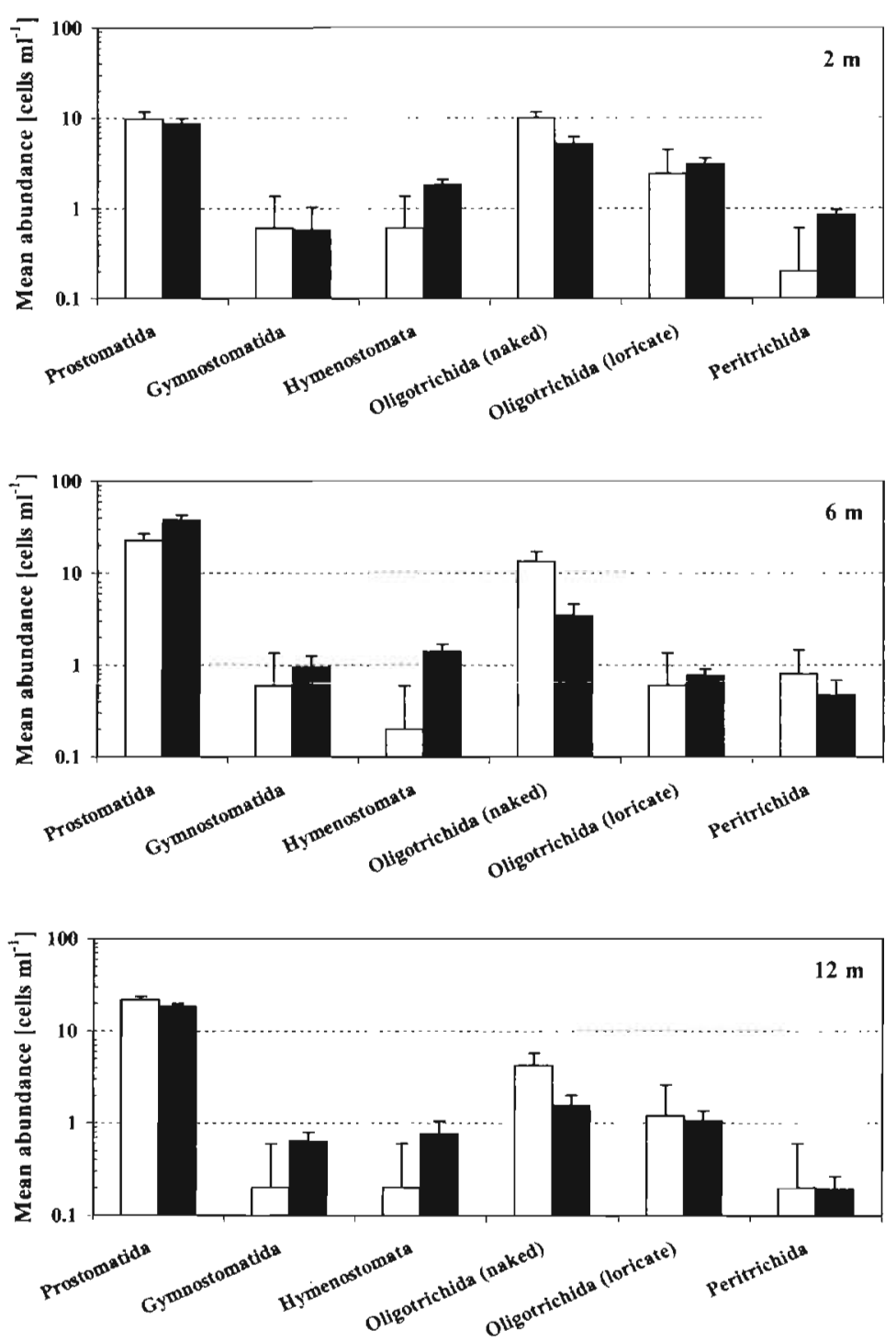

Fig. 1. Abundance of different ciliate groups in Mondsee (21 May 1997) at 3 different depths after live counting (white columns) and QPS (black columns). Mean values in cells $\mathrm{ml}^{-1}+\mathrm{SD}$. Note logarithmic scale
Table 2. Ciliate species identified in Mondsee on 21 May 1997 after live observation and the quantitative protargol stain (QPS). +++: high abundance ( $>1.5$ cells $\left.\mathrm{ml}^{-1}\right),++$ : medium abundance $(0.5$ to 1.5 cells $\left.\mathrm{ml}^{-1}\right),+$ : low abundance $\left(<0.5\right.$ cells $\left.\mathrm{ml}^{-1}\right),-$ : not found

\begin{tabular}{|lcc|}
\hline Species & Live & QPS \\
\hline Prostomatida & & \\
Balanion planctonicum & - & +++ \\
Coleps spetai & ++ & +++ \\
Urotricha agilis & - & + \\
Urotricha apsheronica & + & + \\
Urotricha furcata & - & +++ \\
Urotricha spp. & ++ & ++ \\
Gymnostomatida & & \\
Askenasia volvox & + & + \\
Lagynophrya acuminata & - & + \\
Mesodinium sp. & - & + \\
Monodinium balbiani & - & + \\
Spathidium sp. & - & + \\
Hymenostomata & & \\
Cyclidium spp. & - & + \\
Histobalantium bodamicum & + & ++ \\
Uronema sp. & - & + \\
Oligotrichida & & \\
Codonella cratera & + \\
Halteria chlorelligera & + & + \\
Halteria grandinella & - & + \\
Pelagostrombidium fallax & ++ & ++ \\
Pelagostrombidium mirabile & + & ++ \\
Rimostrombidium lacustris & - & + \\
Rimostrombidium sp. & - & + \\
Strobilidium hyalinum & - & ++ \\
Strombidium viride & + & + \\
Tintinnidium fluviatile & - & ++ \\
Tintinnopsis cylindrata & - & + \\
Hypotrichida & + & ++ \\
Aspidisca sp. & & \\
Peritrichida & - \\
Vorticella aquadulcis complex & + & ++ \\
Vorticella natans & - & + \\
Peritrich swarmers & & + \\
\hline & & + \\
\hline
\end{tabular}

methods. Cell counts with the QPS method reached $34 \%$ (C. margaritaceum), $64 \%$ (C. glaucoma) and $75 \%$ ( $H$. grandinella) of the respective live counts (Table 1 ). As with in the field samples the direct live counts resulted in higher variability of the obtained results than the QPS.

\section{Species composition}

Twenty-eight pelagic ciliate species could be distinguished. The ciliate community was mainly composed by prostomatids and oligotrichs. Only 11 of the 28 species could be distinguished in the live samples, about
$60 \%$ of all determined species were identified exclusively by means of the QPS (Table 2). Mainly rare, small and fast moving species were overlooked or lumped with other species in the live observations.

\section{Cell dimensions}

Shrinkage of ciliate cells after the QPS was observed on both field samples and ciliate cultures. The aloricate species Halteria grandinella, Cyclidium glaucoma and Cinetochilum margaritaceum shrank to less than $20 \%$ of their original live volumes. The cell volume of the lorica-bearing species Codonella crat- 
era was reduced less, namely to $25 \%$ of the live volume. Only the armoured prostomatid species Coleps spetai did not shrink significantly ( $p>0.05$ ); its cell volume after the QPS was $88 \%$ of the live volume (Table 3 ).

Due to that shrinkage of cells during the QPS, Jerome et al. (1993) suggested dividing cell volumes calculated after that preparation by an average factor of 0.4 to estimate live cell volumes. Our data clearly demonstrate the need for specific conversion factors in different ciliate groups due to the observed differences in shrinking. Conversion factors between 0.88 for the armoured Coleps spetai and 0.32 for aloricate species had to be applied to approximate the respective live cell volumes. An average factor would underestimate cell volumes of species shrinking more than others, whereas volumes of species hardly shrinking at all (e.g. C. spetall would be overestimated by almost $300 \%$.

\section{Heterotrophic and mixotrophic flagellates}

\section{Cell numbers}

Mean heterotrophic and mixotrophic flagellate abundance in Mondsee calculated after live counts ranged from about 300 to 2000 cells $\mathrm{ml}^{-1}$ at 12 and $2 \mathrm{~m}$ depth, respectively. Cell numbers after the QPS were less variable and highly significantly lower $(\mathrm{p}<0.01)$ at all 3 depths. The average heterotrophic flagellate number from the 3 depths investigated was about 1400 cells $\mathrm{ml}^{-1}$ after live counting compared to a highly significant, lower ( $p<0.01$ ) number (about 450 cells $\mathrm{ml}^{-1}$ ) after QPS (Table 1 . Fig. 2).

\section{Cell dimensions}

Cell volumes for 4 flagellate species in vivo (Dinobryon bavaricum, $D$. divergens, Dinobryon sp. and Salpingoeca sp.) were 229 to $328 \mu^{3}$ cell $^{-1}$ for the 3 Dinobryon species and $140 \mathrm{\mu m}^{3} \mathrm{cell}^{-1}$ for Salpingoeca sp. After fixation and QPS these cell volumes significantly ( $p<$ 0.05 ) declined to $51-70 \%$ for the 3 Dinobryon species and $37 \%$ for Salpingoeca sp. (Table 3).
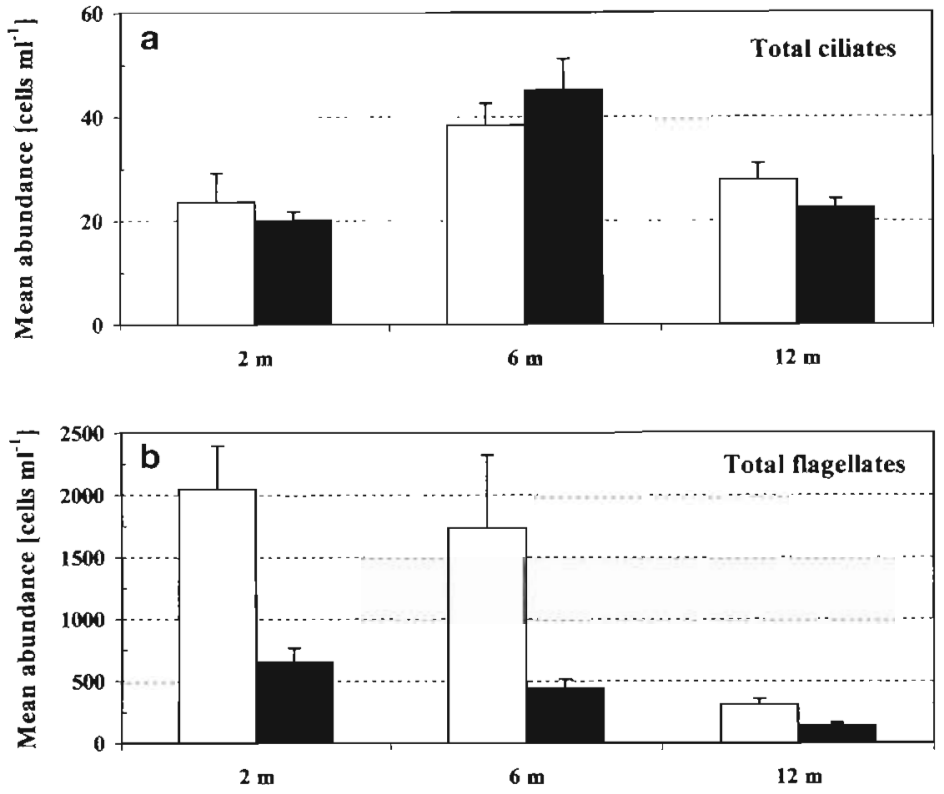

Fig. 2. Abundance of (a) total ciliates and (b) total heterotrophic and mixotrophic flagellates in Mondsee (21 May 1997) at 3 different depths. Comparison of live counts (white columns) and QPS counts (black columns). Mean values in cells $\mathrm{ml}^{-1}+\mathrm{SD}$

Table 3. Comparison of cell volumes for ciliates and flagellates after live observation and the quantitative protargol stain (QPS). Mean \pm SD. P: power of $t$-test (0.00-1.00), L/Q: percentage of cell volumes obtained by means of QPS preparations (live cell volumes $=100 \%$ ), D; difference between treatments, ' highly significant shrinkage due to QPS ( $\mathrm{p}<0.01)$, n: number of measured cells, Mann-Whitney test due to lacking normality distribution of data

\begin{tabular}{|c|c|c|c|c|c|c|c|}
\hline & $\mathrm{n}$ & $\begin{array}{c}\text { Live } \\
\left(\mu \mathrm{m}^{3} \mathrm{cell}^{-1}\right)\end{array}$ & $\mathrm{n}$ & $\begin{array}{c}\text { QPS } \\
\left(\mu \mathrm{m}^{3} \mathrm{cell}^{-1}\right)\end{array}$ & $\mathrm{P}$ & $\begin{array}{l}\mathrm{L} / \mathrm{Q} \\
(\%)\end{array}$ & D \\
\hline $\begin{array}{l}\text { Ciliates } \\
\text { Halteria } \\
\text { grandinella }\end{array}$ & 20 & $10856 \pm 2296$ & 30 & $1356 \pm 358$ & 1.00 & 12 & $\because$ \\
\hline $\begin{array}{l}\text { Cyclidium } \\
\text { glaucoma }\end{array}$ & 30 & $1371 \pm 737$ & 30 & $210 \pm 118$ & 1.00 & 15 & 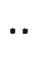 \\
\hline $\begin{array}{l}\text { Cinetochilum } \\
\text { margaritaceum }\end{array}$ & 20 & $5835 \pm 2114$ & 30 & $959 \pm 272$ & 1.00 & 16 & $\cdots$ \\
\hline $\begin{array}{l}\text { Coleps } \\
\text { spetai }\end{array}$ & 30 & $49703 \pm 9962$ & 30 & $43907 \pm 12903$ & 0.05 & 88 & \\
\hline $\begin{array}{l}\text { Codonella } \\
\text { cratera }\end{array}$ & 30 & $67499 \pm 44358$ & 30 & $16999 \pm 7841$ & 1.00 & 25 & $\because$ \\
\hline \multicolumn{8}{|l|}{ Flagellates } \\
\hline $\begin{array}{l}\text { Dinobryon } \\
\text { bavaricum }\end{array}$ & 49 & $229 \pm 78$ & 50 & $160 \pm 67$ & $\sim$ & 70 & 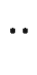 \\
\hline $\begin{array}{l}\text { Dinobryon } \\
\text { divergens }\end{array}$ & 49 & $328 \pm 137$ & 50 & $229 \pm 104$ & $\sim$ & 70 & $\because$ \\
\hline $\begin{array}{l}\text { Dinobryon } \\
\text { sp. }\end{array}$ & 49 & $272 \pm 82$ & 50 & $138 \pm 56$ & $\sim$ & 51 & $\cdots$ \\
\hline $\begin{array}{l}\text { Salpingoeca } \\
\text { sp. }\end{array}$ & 49 & $137 \pm 35$ & 50 & $50 \pm 17$ & $\sim$ & 37 & $\cdots$ \\
\hline
\end{tabular}




\section{DISCUSSION}

Different methods are described for quantitative protozooplankton analysis; however, commonly applied fixatives and staining methods are known to reduce both cell numbers (Sime-Ngando et al. 1990, SimeNgando \& Groliere 1991, Leakey et al. 1994) and cell dimensions (Choi \& Stoecker 1989, Jerome et al. 1993). Due to the sensitivity of the cells to fixation and staining treatments, direct live observation seems to be the most gentle way to investigate protozoa. Different quantitative live observation techniques for protozoa have been described so far (Dale \& Burkill 1982, Sime-Ngando et al. 1990, Massana \& Güde 1991). A drawback of these methods is that microscopic observation has to be done within a few hours after sampling. Longer transportation or storage times could lead to a loss of sensitive species due to changing temperatures or water chemistry (e.g. pH, oxygen). Additionally, encystment or excystment effects as well as grazing could alter the original species composition. Further, the handling of small and fast moving organisms requires some experience. To avoid these difficulties in live observation, most ecological studies are performed on fixed samples. Flagellates are commonly fluorescently labeled and quantified by means of epifluorescence microscopy (Caron 1983, Massana \& Güde 1991, Simek et al, 1995). Sedimented Lugol samples after Utermöhl (1958) are often used to enumerate pelagic ciliates (Leakey et al. 1993). However, these methods only provide poor taxonomic information, making species identification almost impossible in most cases. Additionally, most modern taxonomic literature for ciliates is based on silver staining techniques (e.g. Foissner et al. 1991, 1992, 1994, 1995, Foissner \& Pfister 1997). Unfortunately, these common taxonomic methods (revised in Foissner 1991) provide only rough quantitative data

Since comprehensive ecological studies require both quantitative and reliable taxonomic data, the QPS seems to be a promising compromise method. Interestingly, there are only a few reports of the application of QPS in freshwater systems (Skibbe 1994, Macek et al. 1996. Mayer et al. 1997, Pfister 1997) but numerous records for marine populations, all published by Montagnes and co-workers (e.g. Montagnes et al. 1988a, b, Martin \& Montagnes 1993, Montagnes \& Taylor 1994). Consequently, most quality checks concerning the QPS have been performed for marine ciliates only (Montagnes \& Lynn 1987, Jerome et al. 1993). However, freshwater habitats are characterized by a different species composition and altered chemical conditions. We suggest that these factors could possibly influence shrinkage effects due to fixation.

The protozoan population sampled from Mondsee on 21 May 1997 represented a typical community for mesotrophic lakes. A typical ciliate community (Oligotrichetea, Foissner \& Berger 1996) for stagnant freshwaters was determined. Prostomatida (Coleps spetai, Balanion planctonicum and Urotricha spp.) and Oligotrichida (Halteria grandinella, Codonella cratera, Strobilidium spp. and tintinnids) were identified as the main species. The investigated flagellates Dinobryon spp. and Salpingoeca sp. are common species in Mondsee and other standing waters. Therefore, we assume that our data may be representative for many other freshwater habitats.

Ciliates were commonly well stained by our modification of the QPS. However, our experience demonstrated that some ciliate groups are better impregnated than others. The QPS gave excellent results for oligotrichs, hypotrichs, cyrtophorids, peritrichs, most gymnostomatids and some hymenostomatids. Unfortunately, some prostomatids and hymenostomatids were poorly stained. Nevertheless, even these species could usually be determined by DIC. Although some taxonomically important characteristics (e.g. movement, color, shape) are lost, more species were distinguished with the QPS method than with the direct live count. Mainly rare, fragile, small and fast moving species were overlooked and partially misidentified in the live samples. For example, the abundant Balanion planctonicum was not distinguishable from small urotrichs and strobilids by our live observation but clearly identifiable in the QPS preparations. Consequently, we assume that the applied live counting technique produces severe taxonomical irregularities due to overlooking species or lumping some species together with others (cf. Table 2). These difficulties in correct species determination by means of the applied live observation might be one reason in the detected differences of cell numbers. The significantly higher numbers of naked oligotrichs by means of the live counts could be explained by incorrect species identification. Many of these very small and fast moving species could possibly have been small prostomatids which were recognized in the QPS preparations exclusively. The significantly lower numbers of that group in the live counts might support the theory of lumping species together (cf. Table 1, Fig. 1). However, with the applied live counting technique, a reliable identification of such small and fast moving species is almost impossible. On the other hand, total ciliate numbers obtained from QPS counts corresponded well with direct live counts, demonstrating the reliability of quantitative data provided by the QPS for many species.

We are well aware of some limitations in interpreting the data derived from our counts. The main problem is the limited strength of statistical support in some of our findings, which is essentially due to a lack of live data. The small sample sizes (droplets) in live counting pro. 
duced relatively high standard deviations, especially for rare species. Consequently, the power of statistic comparisons is sometimes below a desired level. Nevertheless, small sample sizes were necessary to keep the length of time needed for counting 1 droplet as short as possible. If the counting takes too long, the organisms would burst due to the heat caused by the microscope illumination. A microscope equipped with a cooled stage would allow for longer observation times of larger live samples. However, in our experimental setup we tried to reduce these drawbacks to the greatest possible extent. Unfortunately, rare and very small species cannot reliably be quantified by means of the applied live counting technique and spatial heterogeneity in a water sample interferes with the counts. Nevertheless, we are convinced that we have pointed to some important effects when a quantification of pelagic protozoa requires one of the 2 methods compared in this study.

Another criterion investigated was the shrinkage of fixed cells. The effect of the QPS on cell size has been investigated by Jerome et al. (1993) on 4 ciliate and a dinoflagellate species. Cell volumes after the QPS shrank to about $26 \%$ of live volume for Strombidium acutum and to about $65 \%$ of live volume for Euplotes $\mathrm{sp}$. From their results, the authors proposed a rough conversion factor of 0.4 for biomass calculations after the QPS. Our results for freshwater samples showed even higher and remarkable species-specific shrinkage rates. After the QPS aloricate species shrank more than loricate ones. Almost no shrinkage could be observed for Coleps spetai. We assume that the armoured plates covering the whole cell protect this species from shrinkage. Considering such species-specific differences in shrinkage, an application of generalized conversion factors for biomass calculations from QPS preparations is problematic. We propose that cell volumes for biomass calculations should be determined on living cells whenever possible. If biomass calculations from QPS preparations are necessary, conversion factors depending on the cortical properties of individual species should be previously established to avoid high errors in cell volume calculations. Additionally, the influence of the physiological and nutritional state of a cell on size effects during fixation (e.g. Sieracki et al. 1987) has to be tested in further laboratory studies.

We found almost no information in the literature concerning the quantification of flagellate populations by

Table 4. Comparison of the advantages and disadvantages after direct live observation and the quantitative protargol stain (QPS)

\begin{tabular}{|c|c|}
\hline Live & QPS \\
\hline \multicolumn{2}{|c|}{ Advantages } \\
\hline - No loss of cells due to fixation or staining procedure & $\begin{array}{l}\text { - Provides taxonomic and quantitative information simulta- } \\
\text { neously }\end{array}$ \\
\hline - 'Real' live dimensions without swelling or shrinking effects & $\begin{array}{l}\text { - Provides permanent slides, Bouin-fixed samples can be } \\
\text { stored for several months }\end{array}$ \\
\hline $\begin{array}{l}\text { - Some taxonomically important characteristics (movement, } \\
\text { shape, color, contractile vacuole) only visible in living cells }\end{array}$ & $\begin{array}{l}\text { - Some taxonomically important characteristics (infra- } \\
\text { ciliature, nuclear apparatus, cortical structures, flagella) } \\
\text { best visible in protargol impregnations }\end{array}$ \\
\hline & - Lower variability in cell counts than direct live counts \\
\hline & $\begin{array}{l}\text { - Rare, epiphytic or colonial species can be recorded with } \\
\text { relatively high possibility due to a higher sample volume } \\
\text { compared to live counts }\end{array}$ \\
\hline \multicolumn{2}{|c|}{ Disadvantages } \\
\hline - Immediate sample analysis essential & - Complex and relative time-consuming staining protocol \\
\hline $\begin{array}{l}\text { - Difficult and specialized taxonomic determination and } \\
\text { handling of living cells (especially for small and fast } \\
\text { moving species) }\end{array}$ & $\begin{array}{l}\text { - Expensive laboratory equipment and (toxic) chemicals } \\
\text { necessary }\end{array}$ \\
\hline - Difficulty of measurements on fast moving cells & $\begin{array}{l}\text { - Not accurate for flagellates (no possibility to distinguish } \\
\text { between autotrophs and heterotrophs) }\end{array}$ \\
\hline $\begin{array}{l}\text { - Determined cell numbers are highly variable due to low } \\
\text { sample volumes (especially for rare, epiphytic or colonial } \\
\text { species) }\end{array}$ & $\begin{array}{l}\text { - Loss of sometimes essential information in ciliate } \\
\text { taxonomy (movement, shape, color, contractile vacuole) }\end{array}$ \\
\hline $\begin{array}{l}\text { - Possible bias due to excystment or death of cells during } \\
\text { observation }\end{array}$ & $\begin{array}{l}\text { - Possible loss of specific (fragile) species due to fixation } \\
\text { and/or staining procedure }\end{array}$ \\
\hline - No permanent preparations (except micrographs) possible & $\begin{array}{l}\text { - Possible deformation of cells in combination with high } \\
\text { shrinkage effects }\end{array}$ \\
\hline
\end{tabular}


the QPS. Although previous studies indicated the clarity of quantitatively protargol-stained flagellates (Skibbe 1994), no quantitative data was presented. However, the micrograph presented in Skibbe's (1994) study shows choanoflagellates to be a group that results in better QPS preparations than other flagellates. Our results from natural flagellate communities indicate that their quantification by means of the QPS does not seem to be accurate (Table 1, Fig. 2 and Sonntag et al. unpubl.). The reason for the severe underestimation of heterotrophic flagellates after the QPS is that it is almost impossible to distinguish them from autotrophic species. Possibly, many heterotrophic cells have been identified as autotrophic ones in the QPS preparations and have therefore been excluded from our counts. Additionally, even the easily recognizable Dinobryon species were found in considerably lower numbers after the QPS. A reason for the underestimation of these loricate species could be that many cells leave their lorica during fixation. Since we found many empty loricae on the slides, this might be an obvious explanation. These cells without their specific lorica are not easy to identify in the protargol slides and may therefore have been overlooked. Hence, we conclude that the QPS method is not accurate for an enumeration of heterotrophic and mixotrophic flagellates in field studies. Interestingly, shrinkage of the investigated flagellates was lower than for most ciliate species observed (Table 3 ). Since the investigated flagellates were all loricate, an influence of different cortical properties of these 2 protozoa groups could be a possible explanation. However, the 4 flagellate species were abundant at the sampling occasion, but cannot be seen as only representatives of a natural flagellate community. Nevertheless, we assume that considerable shrinkage effects due to the QPS can also be expected for many other naturally occurring flagellate species (Sonntag et al. unpubl.).

Based on the points discussed above and summarized in Table 4 , we recommend the application of both tested methods to determine cell numbers and dimensions of pelagic freshwater protozoa. Live observation is essential for the investigation of pelagic flagellates. For ciliates, the QPS makes routine sampling possible, even with high sample numbers in a short time interval. This method results in a good estimation of ciliate abundance and a relatively simple determination of most species. Permanent slides allow for further investigations to be made, even years after sampling. However, calculations of cell volumes of both flagellates and ciliates based on QPS preparations have to be evaluated with some caution. Therefore, an additional investigation of live samples at least at applicable time intervals is essential to obtain accurate cell dimensions and additional information for species determination.
Acknowledgements. We thank the staff of the Institute of Limnology, Austrian Acaderny of Sciences, Mondsee, especially C. Skolaut for sampling assistance. Special thanks to I. Bruchmüller for cultures of Cryptomonas and to A. Nauwerck, R. Psenner and R. Sommaruga for critical comments and improving the clarity of the manuscript. Three anonymous reviewers are acknowledged for numerous helpful comments on an earlier version of the manuscript. Thanks to $\mathrm{S}$. Wickham for improvement of our English and A. Lochs for help with statistical questions. This work was financially supported by the FWF (project no. P10306/BIO to A. Nauwerck).

\section{LITERATURE CITED}

Arndt $H$ (1994) Protozoen als wesentliche Komponente pelagischer Ökosysteme von Seen. In: Die Urtiere - eine verborgene Welt, Vol 71. Kataloge des OÖ Landesmuseums NF, Linz, p 111-147

Berger $H$, Foissner W, Kohmann F (1997) Bestimmung und Ökologie der Mikrosaprobien nach DIN 38 410. Fischer, Stuttgart

Caron DA (1983) Technique for enumeration of heterotrophic and phototrophic nanoplankton, using epifluorescence microscopy, and comparison with other procedures. Appl Environ Microbiol 46:491-498

Choi JW, Stoecker DK (1989) Effects of fixation on cell volume of marine planktonic protozoa. Appl Environ Microbiol 55: $1761-1765$

Dale T, Burkill PH (1982) 'Live counting' - a quick and simple technique for enumerating pelagic ciliates. Ann Inst Océanogr 58:267-276

Fenchel T (1987) Ecology of protozoa. Springer, Berlin

Foissner W (1988) Taxonomic and nomenclatural revision of Sládecek's list of ciliates (Protozoa: Ciliophora) as indicators of water quality. Hydrobiologia 166:1-64

Foissner W (1991) Basic light and scanning electron microscopic methods for taxonomic studies of ciliated protozoa. Eur J Protistol 27:313-330

Foissner W, Berger H (1996) A user-friendly guide to the ciliates (Protozoa, Ciliophora) commonly used by hydrobiologists as bioindicators in rivers, lakes, and waste waters, with notes on their ecology. Freshwat Biol 35:375-482

Foissner W, Pfister G (1997) Taxonomic and ecologic revision of urotrichs (Ciliophora, Prostomatida) with three or more caudal cilia, including a user-friendly key. Limnologica 27 : $311-347$

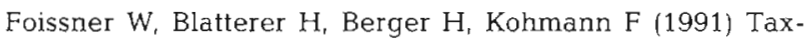
onomische und ökologische Revision der Ciliaten des Saprobiensystems - Band I: Cyrtophorida, Oligotrichida, Hypotrichia, Colpodea, Vol 1/91. Informationsberichte des Bayer Landesamtes für Wasserwirtschaft, Munich, p $1-478$

Foissner W, Berger $H_{4}$ Kohmann F (1992) Taxonomische und ökologische Revision der Ciliaten des Saprobiensystems - Band II: Peritrichia, Heterotrichida, Odontostomatida, Vol 5/92. Informationsberichte des Bayer Landesamtes für Wasserwirtschaft, Munich, p 1-502

Foissner W, Berger $H_{1}$ Kohmann F (1994) Taxonomische und ökologische Revision der Ciliaten des Saprobiensystems - Band III: Hymenostomata, Prostomatida, Nassulida, Vol 1/94. Informationsberichte des Bayer Landesamtes für Wasserwirtschaft, Munich, p 1-548

Foissner W, Berger H, Blatterer H, Kohmann F (1995) Taxonomische und ökologische Revision der Ciliaten des Saprobiensystems - Band IV: Gymnostomatea, Loxodes, Suctoria, Vol 1/95. Informationsberichte des Bayer Landesamtes für Wasserwirtschaft, Munich, p 1-540 
Fowler J, Cohen L (1990) Practical statistics for field biology. Open University Press, Milton Keynes

Guillard RRL, Lorenzen CJ (1972) Yellow-green algae with chlorophyllide. Can J Phycol 8:10-14

Haas LW (1982) Improved epifluorescence microscopy for observing planktonic micro-organisms. Ann Inst Océanogr 58:261-266

Hall JA, Barret DP, James MR (1993) The importance of phytoflagellate, heterotrophic flagellate and ciliate grazing on bacteria and picophytoplankton sized prey in a coastal marine environment. J Plankton Res 15:1075-1086

Jerome CA, Montagnes DJS, Taylor FJR (1993) The effect of the quantitative protargol stain and Lugol's and Bouin's fixatives on cell size: a more accurate estimate of ciliate species biomass. J Eukaryot Microbiol 40:254-259

Leakey RJG, Burkill PH, Sleigh MA (1993) Planktonic ciliates in Southampton water: quantitative taxonomic studies. J Mar Biol Assoc UK 73:579-594

Leakey RJG, Burkhill PH, Sleigh MA (1994) A comparison of fixatives for the estimation of abundance and biovolume of marine planktonic ciliate populations. J Plankton Res 16 : 375-389

Macek M, Simek K, Pernthaler J, Vyhnálek V, Psenner R (1996) Growth rates of dominant planktonic ciliates in two freshwater bodies of different trophic degree. J Plankton Res 18:463-481

Martin AJ, Montagnes DJS (1993) Winter ciliates in a British Columbian fjord: six new species and an analysis of ciliate putative prey. J Eukaryot Microbiol 40:535-549

Massana R, Güde H (1991) Comparison between three methods for determining flagellate abundance in natural waters. Ophelia 33:197-203

Mayer J, Dokulil M, Salbrechter M, Berger M, Posch T, Pfister G, Kirschner AKT, Velimirov B, Steitz A, Ulbricht T (1997) Seasonal successions and trophic relations between phytoplankton, zooplankton, ciliate and bacteria in a hypertrophic shallow lake in Vienna, Austria. Hydrobiologia 342/343:165-174

Montagnes DJS, Lynn DH (1987) A quantitative protargol stain (QPS) for ciliates: method description and test of its quantitative nature. Mar Microb Food Webs 2:83-93

Montagnes DJS, Taylor FJR (1994) The salient features of five marine ciliates in the class Spirotrichea (Oligotrichia), with notes on their culturing and behaviour. J Eukaryot Microbiol 41:569-586

Montagnes DJS, Lynn DH, Roff JC, Taylor WD (1988a) The

Editorial responsibility: Karel Simek,

Ceské Budèjovice, Czech Republic annual cycle of heterotrophic planktonic ciliates in the waters surrounding the Isles of Shoals, Gulf of Maine: an assessment of their trophic role. Mar Biol 99:21-30

Montagnes DJS, Lynn DH, Stoecker DK, Small EB (1988b) Taxonomic descriptions of one new species and rediscription of four species in the family Strombidiidae (Ciliophora, Oligotrichida). J Protozool 35:189-197

Müller H (1991) Pseudobalanion planctonicum (Ciliophora, Prostomatida): ecological significance of an algivorous nanociliate in a deep meso-eutrophic lake. J Plankton Res 13:247-262

Pfister G (1997) Die saisonale Entwicklung der Ciliatengemeinschaft eines eutrophen Stadtgewässers - Alte Donau in Wien (Österreich). 32. Konferenz der IAD, Limnologische Berichte Donau 1997, Band I, Vienna, p 261-264

Porter KG, Sherr EB, Sherr BF, Pace M, Sanders RW (1985) Protozoa in planktonic food webs. J Protozool 32:409-415

Sherr EB, Caron DA, Sherr BF (1993) Staining of heterotrophic protists for visualization via epifluorescence microscopy. In: Kemp PF, Sherr BF, Sherr EB, Cole JJ (eds) Handbook of methods in aquatic microbial ecology. Lewis Publishers, London, p 213-227

Sieracki ME, Haas LW, Caron DA, Lessard EJ (1987) Effect of fixation on particle retention by microflagellates: underestimation of grazing rates. Mar Ecol Prog Ser 38:251-258

Sime-Ngando T, Groliere CA (1991) Effets quantitatifs des fixateurs sur la conservation des ciliés planctoniques d'eau douce. Arch Protistenkd 140:109-120

Sime-Ngando T, Hartmann HJ, Groliere CA (1990) Rapid quantification of planktonic ciliates: comparison of improved live counting with other methods. Appl Environ Microbiol 56:2234-2242

Šimek K, Bobková J, Macek M, Nedoma J, Psenner R (1995) Ciliate grazing on picoplankton in a eutrophic reservoir during the summer phytoplankton maximum: a study at the species and community level. Limnol Oceanogr 40: $1077-1090$

Skibbe O (1994) An improved quantitative protargol stain for ciliates and other planktonic protists. Arch Hydrobiol 130 $339-347$

Sládeček V (1973) System of water quality from the biological point of view. Arch Hydrobiol Beih Ergebn Limnol 7:I-IV, $1-218$

Utermöhl H (1958) Zur Vervollkommnung der quantitativen Phytoplankton Methodik. Mitt Int Ver Theor Angew Limnol 9:1-38

Submitted: June 1, 1998; Accepted: November 14, 1998 Proofs received from author(s): June 21, 1999 